\title{
The impact of Brand Trust, Love and Passion on Positive Word of Mouth
}

\author{
Dr. Muhammad Zeeshan*1, Mishal Nafees ${ }^{2}, \&$ Bilal Mustafa $^{3}$ \\ 1,2,3 UCP Business School, University of Central Punjab, Lahore, Pakistan
}

\begin{abstract}
Brands try to initiate and build strong relationships with their customers in order to overcome the rising local and international competition in apparel and other industries. Previous research suggests that brand addiction is one of the most significant ways through which consumer engage with brands. Meanwhile, it is a sort of consumer-brand relationship by which brands could enable themselves to build and sustain strong long-term relationships in order to get competitive edge over other business rivalries in the market. The purpose of this study is to demonstrate the relationship of brand addiction with some of its possible antecedents and outcomes. In order to address the research problem, data have been collected from a convenience sample in apparel industry of Pakistan. Multiple regression analysis has been used in order to analyze the results. Findings suggest that brand trust is positively correlated with brand addiction whereas brand love and brand passion do have positive impact on brand addiction that will lead to generate positive word of mouth. Moreover, this research contributes in the existing literature of marketing, as well as provides favorable insight to the practitioners and marketers.
\end{abstract}

\section{Introduction}

Brand addiction is one of the significant ways by which buyer engross with brands (Fajer and Schouten, 1995). Addictive behavior is emerged in shopping, playing, pornography, plastic surgery, overeating, dietetic supplement procedure and others (Murphy et al., 2014). A neoteric research (Loessl et al., 2008) highlights that handy relationships between brand and consumers may lead consumers toward brand addiction, meanwhile studies also provide evidences that the bounded relationships of consumer with specific brand activate the consumers brain area called Insula and this area is liable of addictive behavior such as addiction of nicotine (Klaas et al., 2005) and addiction of alcohol (Myrick et al., 2007).

Brands play a significant and central role in humans consumption behavior as well as define their lives (Ahuvia, 2005; Wallendorf and Arnould, 1988). Some consumers might be engaged into true vogue of some brands because tight relationship attaches consumers with their selected brands (Fournier, 1998). Associations amongst customers and brands such as brand identification (Escalas and Bettman, 2003)and brand trust (Hess, 1995) arise as cores to many branding studies (Albert et al., 2013) and influencing concepts such as brand attachment (Park et al., 2006), brand passion (Swimberghe et al., 2014) and brand love (Carroll and Ahuvia, 2006) also have impact on consumer behavior (Albert et al., 2013). Among addic-

*Corresponding author.

Email: drzeeshan@ucp.edu.pk tive behaviors of consumers toward different brands, most of the research emphasizes on compulsive buying behavior (Cui et al., 2018). However, the phenomena of customer brand associations include variety of emotions from unintentional emotions to passionate love that ultimately leads to addictive enthusiasm (Fournier, 1998).

As addictive behavior has different results from those of ordinary consumption behavior $\left(\mathrm{O}^{\prime}\right.$ Guinn and Faber, 1989).This phenomenon of brand addiction remains new and there is need to explore the relationship of brand addiction with different types of consumerbrand relationships such as brand trust, brand loyalty, brand liking, brand passion, brand attachment, and others (Cui et al., 2018). Meanwhile, to provide the in depth insight of the relationship of consumer and brand, there is need to elucidate that how the phenomenon of brand addiction would function in its integrated framework with some of its antecedents as well as some of positive consequences that may involve other important factors (Cui et al., 2018) such as word of mouth and others. So this study is responding to the contemporary calls for future research into addictive behaviors of the consumers (Cui et al., 2018) by highlighting the impact of some of the consumers emotional states such as brand trust, brand love, brand passion on their addictive behavior toward particular brand. In addition to it, this study also highlighted the impact of brand addition on other behavioral aspects such as word of mouth in order to strengthen the literature of consumer-brand relationship in marketing. 
This paper begins with reviewing the previous literature on different consumer brand relationships as well as diffident variables and addictive activities in regards to address the significant problems. The following section narrates the procedure of data gathering, methodology and methodological technique, data analysis and interpretation of the results. Lastly, the discussion, conclusion, limitations and future research sections have been discussed.

\section{Literature Review}

\subsection{Brand Addiction}

Customarily, addictive behaviors are pertaining to the drugs and alcohol addictions (American Psychiatric Association, 2000). As in a recent study, Fournier and Alvarez (2013) highlight some negative characteristics of consumers addictive relationships with particular brands by reasoning from Hirschman (1992) on drugs and alcoholic addicts. To draw ties between the phenomena of addiction of alcohol, drugs with brand addiction seeks theoretical and empirical support, which is insufficient in present literature (Cui et al., 2018). Similarly, previous studies identified that the word addiction should not be associate entirely with the drugs or narcotics because since associating this term exclusively to narcotics or drugs create an artificial dichotomy that narrate the term with the similar condition, when narcotics or drugs are not included (Alexander, 2014). Indeed, the term addiction should be comprehended beyond the territories of substance abuse (Paulus and Stewart, 2014). Similarly, any source which could be responsible and capable of stimulating an individual, could become addictive (Alavi et al., 2012).

Brand addiction can be defined as a customers psychological condition that relates to a self-branding consortium apparent in everyday life as well as includes positive gratification and affectivity with a peculiar brand and persistent desire of possessing the products/services of that particular brand, which could be identified by eleven useful features such as acquisitiveness, follow up, dependence hoarding, fascination, , lack of self-control, support, outward inspiration, resistance to substitutes, diligence within affordability and thought occupancy (Mrad and Cui, 2017). In other words, an individual/consumers positive efforts to satisfy him/her-self through constant acquisition of the products or services of a particular brand as well as being identified by this specific brand could be known as a state of brand addiction.

It is crucial to note that the above eleven features of brand addiction are derived from consumers experience with particular brands that differentiate the concept of brand addiction from the concepts of substance abuse, as well as from other pathological addictive be- haviors, however in broader context the concept of brand addiction is added in the category of addiction, besides results of a previous study by (Mrad and Cui, 2017)on Brand Addiction did not suggest any harmful consequences. However, the concept of brand addiction is overlapping with the concept of compulsive buying and it looks reasonable to design a holistic view of brand addiction with in the typologies of consumerbrand relationships, a salient difference between brand addiction and uncontrollable purchasing is that, compulsive buying is concentrated on the common expenditure and consumption whereas brand addiction specifically emphasizes on a specific brand (Mrad and Cui, 2017). Similarly some speculations of researchers were also identified that addiction to brand does exist (Park et al., 2006; Reimann et al., 2012). Moreover many researchers could factually identify the consumers addictive behaviors toward different brands and could build distinctive theoretical models in the area of publicizing, behavioral addiction, psychiatry and consumers behavior or psychology by using the notion of brand addiction (Mrad and Cui, 2017). Table 1 outlines the definitions of the main constructs.

\subsection{Brand Trust}

Brand trust has been observed as an essential in many of the researches conducted earlier (Doney and Cannon, 1997; Moorman et al., 1992). Chaudhuri and Holbrook (2001) described brand trust as the willingness of the average consumer to rely on the ability of the brand to perform its stated function. whereas brand trust also offers a greater lens by which a firm can scrutinize and evaluate the customer behavioral comebacks. Brand trust contains five constitutes; first, brand trust includes customer readiness or willingness to make him/herself at steak, by relying on the assurance of the worth of the particular brand. Second, it is distinct with the sense of self-assurance and safety. Third, Brand trust includes common expectation as trust can't prevail without the probability of error. Fourth, brand trust is a constitute of positive results and lastly, brand trust needs to create a frame of mind with the brand regarded as consistent, dependable , trustworthy (Doney and Cannon, 1997).

Doney and Cannon (1997) also emphasized that Trust is specifically pertinent to circumstances of improbability, for example amongst the different brands when superior and inferior differences occur, especially the trust factor reduces the improbability in the setting where customer senses are vulnerable because customer can stand with the brand they trust. Brand trust is theorized as prominent feature in any company's progress (Morgan and Hunt, 1994). Further, Doney and Cannon (1997) stated as brand trust rises later customer's assessment of firm's assistance. For example, when a firm provides assurance to the customer with 
Table 1: Constructs and Definitions

\begin{tabular}{ll}
\hline Constructs & Definitions \\
\hline Brand Addiction: & $\begin{array}{l}\text { An individual consumers psychological state that pertains to a self- } \\
\text { brand relationship manifested in daily life and involving positive af- } \\
\text { fectivity and gratification with a particular brand and constant urges } \\
\text { for possessing the brands products/services (Mrad and Cui, 2017). } \\
\text { The degree of passionate emotional attachment a satisfied consumer } \\
\text { has for a particular trade name (Carroll and Ahuvia, 2006) p. 81). } \\
\text { The willingness of the average consumer to rely on the ability of the } \\
\text { brand to perform its stated function (Chaudhuri and Holbrook, 2001) } \\
\text { p. 82). } \\
\text { Word of mouth Communication (WOM) or by word of mouth commu- } \\
\text { nication is a communication process for the provision of advice either } \\
\text { individually or in groups for a product or service that aims to provide } \\
\text { personal information. (Keller, 2007). } \\
\text { A strong emotional connection to a brand that people value, find im- } \\
\text { portant, desire to own and/or use, incorporate into their identity, and } \\
\text { invest resources in over a period of time }\end{array}$ \\
\hline
\end{tabular}

loyalty, security, trustworthiness, for their brands, it automatically creates the sense of brand trust. So by this it can be depicted that brand trust is established and shaped with straight experience of the customer with brand. Brand trust is also examiner as an extensive way that takes place because of customer belief and thoughtfulness customer experiences related to that brand store (Chaudhuri and Holbrook, 2001). Ganesan (1994) and Selnes (1998) stated that overall satisfaction, in evaluating the consumption knowledge with any particular brand creates the brand trust.

Many researchers have examined that Brand trust also points towards loyalty and this took place by the reason of brand trust capacity of generating vastly esteemed bond (Elena and Jose, 2001). Brand Loyalty is a share of repeated procedure of cherished and prominent relationship that is created from brand trust (Chaudhuri and Holbrook, 2001). There is a lot of support in the literature that brand trust is a great factor of creating brand loyalty $(\mathrm{Wu}, 2010)$. Iglesias et al. (2011) also supported the impact of brand trust in creating brand loyalty.

Literature suggests that (Keh et al., 2007; Shimp and Madden, 1988) brand trust leads to brand loyalty, which is a behavioral stage; similarly brand addiction is an intense mode of behavior that enhances the concept of understanding usual customer behaviors (O'Guinn and Faber, 1989); so as brand trust is directly linked to brand loyalty, similarly, it could be directly related to the brand addiction. Based on the literature review the following hypothesis has been developed:

$H_{1}$ : Brand trust has a positive impact on brand Addic- tion.

\subsection{Brand love}

Brand love is a new marketing concept which supports to elucidate and forecast variation in desired post consumption attitude between gratified customers. It is an expressive and obsessive relationship which exists between a pleased customer and the brand (Carroll and Ahuvia, 2006). Shimp and Madden (1988) theorized eight types of customer-object connection build on tripartite consideration of relational love defined by the research (O'Guinn and Faber, 1989). The gears of customer object ( e.g. brand ) connection is defined by Shimp and Madden (1988) as, judgment yearning, guarantee liking basically are the corresponding item to affection, desire and verdict or assurance apparatuses of relational love affiliation in turn as designated by (Carroll and Ahuvia, 2006). Many researchers are focusing on both expressiveness and obsession while describing the brand love. It was exposed by a study conducted by Whang et al. (2004) that customer can pledge himself/ herself with expressive, passionate and obsessive love with any brand which can take them to erotic affection with the brand for longer time duration. Keh et al. (2007); Shimp and Madden (1988) related loyalty with love that leads to brand love to brand loyalty (Carroll and Ahuvia, 2006). Love with the brand leads its customer towards the feeling of satisfaction as mentioned by the previous studies such as Thomson et al. (2005) described that post consumption satisfaction probably leads to heartwarming affection with the brand for a longer period of time. 
Brand Experience also leads to brand love as Lee (1977) revealed that "love is an attitude" which explains that brand love is also an attitude heading for brand over a period. Brand love is extremely touchy in nature (Carroll and Ahuvia, 2006) by this it was narrated that satisfactory brand perspicacity may take its customer to loving the brand for a great period. Customer delighters also leads the customer towards brand love, if a customer is thrilled with any brand so there is a likelihood that, it leads to grow its emotional linkage with that particular brand (de Almeida and Nique, 2005). Similarly, another researcher explained that when a customer is delighted, he/she expresses the great level of pleasure and astonishment with that brand (Kumar, 1996). Albert et al. (2013) found brand loves 11 dimensions which are as follow : long term relationship, pleasure ,remembrances, passion , attractiveness , matchlessness, self-congruity dreams ,beauty , satisfaction, trust, willingness' to pay. As many researchers mention that brand love leads to brand loyalty which is a behavioral aspect (Keh et al., 2007; Shimp and Madden, 1988), similarly brand addiction is an intense mode of behavior that enhances the concept of understanding usual customer behaviors ( $\mathrm{O}^{\prime}$ Guinn and Faber, 1989) so as brand love is directly related to brand loyalty which is a behavioral stage, so this study proposes that brand love could also be related to the brand addiction. So on the bases of literature hypothesis was developed that: tion.

$\mathrm{H}_{2}$ : Brand love has a positive impact on brand Addic-

\subsection{Brand Passion}

Brand passion is defined as a state of intense longing for union with another. Reciprocated love (union with other) is associated with fulfillment and ecstasy , a state of profound physiological arousal (Hatfield and Walster, 1985). Whereas according to Baumeister and Bratslavsky (1999), passion entail the strong feeling or emotions for other person or object and these feelings are commonly specified by the physiological enthusiasm and the wish to be attached with the object or other person in multiple feelings. In addition to it a previous study defines brand passion as an emotional construct with the involvement of infatuation, obsession and excitation for a brand (Albert et al., 2013). Therefore, interrelated passion encompasses the presence of the partner in the individuals mind; meanwhile this individual romanticizes with the partner and the relationship with this partner, sensual attraction as well as desire for privilege (Hatfield, 1988). Some of the characteristic of the passion are extraneous in consumption context (Albert et al., 2013), because consumers likely do not expect full privilege from the brand (Carroll and Ahuvia, 2006); whereas, if a consumer is showing repurchasing behavior and feel him/her-self loyal toward a specific brand, then it might be possible that he/she anticipates special treatment from that brand in the shape of discount, gifts, etc. As those customers who are committed and loyal with the brand might expect some kind of superior protocols and rewards from their partner brand (Palmatier et al., 2006).

In the context of consumption, to some extant brand passion is defined differently as it is essentially affective, immensely positive attitude towards a particular brand, which ultimately leads to psychological attachment and also affects the pertinent behavioral factors (Bauer et al., 2007) that narrate the fervor and zeal attributes of consumer-brand consortium (Keh et al., 2007) as well as highlights the aroused and deep positive feelings toward a particular brand (Thomson et al., 2005). Similarly, a passionate customer/consumer engrosses in an emotional consortium with the specific brand and feeling amiss when this brand is unavailable (Füller et al., 2008). Hence, brand passion emerges to be a deep feeling of a consumer toward a specific brand (Bauer et al., 2007; Hatfield and Walster, 1985; Keh et al., 2007; Thomson et al., 2005). Therefore, these feelings suggest that consumer is willing to make a passionate relationship with this specific brand as well as he/she feels emotional arousal by dominating and consuming this specific brand (Baumeister and Bratslavsky, 1999). As brand passion is significantly a positive attitudinal state toward a specific brand that affects the pertinent behavioral factors (Bauer et al., 2007). Dick and Basu (1994) identified that consumers psychological state in connection to the brand (brand passion) has an influence on loyalty; similarly, brand passion has a positive impact on the brand commitment (Albert et al., 2013). Concerning the ramification of brand passion, findings suggest that more a consumer values a brand more he or she is willing to pay the higher price for that brand (Aaker and Equity, 1991). Besides brand passion plays a significant role in consumers acceptance to pay a higher price for a certain brand (Bauer et al., 2007).

Similarly, a consumers excitement about or infatuation (brand passion) with a specific brand leads to spread the word of mouth about experience with this brand (Bauer et al., 2007; Füller et al., 2008). As brand addiction is an intense mode of behavior that enhance the concept of understanding usual customer behaviors (O'Guinn and Faber, 1989). As brand passion influences some of the significant behavioral constructs like willingness to pay more and word of mouth (Albert et al., 2013). Similarly, it can assume that brand passion influences brand addiction. So on the basis of previous literature this study hypothesize that:

$\mathrm{H}_{3}$ : Brand passion has a positive impact on brand addiction. 


\subsection{Positive Word of Mouth}

Word of mouth Communication (WOM) or by word of mouth communication is a communication process for the provision of advice either individually or in groups for a product or service that aims to provide personal information (Keller, 2007). Similarly, positive and negative word of mouth could be a vital resource of any business, firm or organization because word of mouth has a numerous impact on either destruction or success of the business. It is also argued that customers are more influenced by the word of mouth rather than the advertising and marketing campaigns by the organizations, because it is considered to be more trustworthy and reliable due to given by individuals to individuals and regardless of self-interest, pulling/pushing a product of specific brand (Silverman, 1997). Additionally, some authors also argued that word of mouth plays more influential role on the behavioral decisions to purchase a particular product or specific brand than formal advertising (Bone, 1995). As word of mouth is a behavioral intention, it could be an outcome of several attitudinal and behavioral intentions such as brand trust, brand love, brand passion, brand commitment and other (Bauer et al., 2007; Carroll and Ahuvia, 2006; Dick and Basu, 1994). Similarly, positive word of mouth is also generated by the brand addictive customers or consumers in order to influence others or initiate individuals to buy and use specific brands products as they are eager to actively guard the brand products and brand image every plausible ways; meanwhile, inspire others to buy and consume similar brand to whom they are addicted (Cui et al., 2018). The findings of previous study also include that those who are addictive to the particular brands put pressure on other individuals and keep convincing them, encourage and inspire them to go and/or purchase and consume the goods of specific addictive brand (Cui et al., 2018). Finding of previous studies suggest that brand addiction elucidate the path of influencing and convincing others to buy and consume specific brand. In other words, brand addiction leads to spread positive words of mouth. So considering word of mouth as an outcome of brand addiction and based on previous literature this study hypothesize that:

$\mathrm{H}_{4}$ : Band Addiction will lead to positive word of mouth.

\subsection{Conceptual Framework}

\section{Methodology}

\subsection{Instrument}

An instrument based on the 31 items was designed in order to collect the data. The measurements are adopted from previous studies. The measure of brand addiction on 7-point Likert scale is adopted from the study of Cui et al. (2018); similarly the scale for measure the brand passion on 7-point likert scale has been adopted from Albert et al. (2013) besides that to measure the construct brand trust on 5-point likert scale has been adopted from Elena and Jose (2001). A 5point likert scale to measure the word of mouth and brand love have been adopted from Carroll and Ahuvia (2006). The internal reliability of each scale is analyzed by the value of coefficient alpha which is best predictor of the internal consistency of the variables (Litwin, 1995). 0.87, 0.83, 0.73, 0.82 and 0.81 respectively which show that the cronbachs alpha values of all measures are above 0.70 . So instruments are reliable and valid. Whereas gender, age, income, education and experience with brand are incorporated as demographics variables.

\subsection{Sample and Data collection}

A self-administrated survey was distributed by hand as well as online to a convenience sample of 450 consumers of apparel industry in Lahore and Faisalabad. Out of which 247 questionnaires were received, at the response rate of $54.88 \%$. 28 questionnaires were fragmented or had missing values and could not be accommodated, so analysis was run on the consummate sample of 209 respondents. Our sample consisted of $51.20 \%$ of the female and $48.80 \%$ of the male whereas majority of our sample size lies between the age of 2130 years that is $88.00 \%$ and rest of them lies between other different age categories. In addition to it, 59.81\% of the total sample has bachelor degree and $32.06 \%$ of the total sample has master degree and rest of them have other education degrees. Besides $39.71 \%$ of the total sample have income between 1-15 thousands PKR whereas $32.70 \%$ have income level between $16-30$ thousands PKR and $18.20 \%$ have the income level between 31-45 thousands PKR and rest of them have other different income levels. A question about the favorite apparel brand has also been asked during and ten different local and international brands were given as options to the respondents. In response to it $17.02 \%$ of the total sample follow Outfitters as their favorite apparel brand and $16.75 \%$ of the respondents follow Junaid Jamshed, a local brand as their favorite brand whereas $13.88 \%$ consider Levis an international brand, $12.88 \%$ consider Khaadi a local brand, $10.02 \%$ have consider Nishat a local brand as their favorite brands and rest of the sample have considered different other local and international brands as their favorite apparel brands. Further, $43.06 \%$ of the respondents have $1-3$ years of experience of their favorite brand and $30.14 \%$ of the respondents have 4-6 years of experience with their favorite apparel brand and rest of them have either less than 1 year of experience or more than 9 years of experience. 


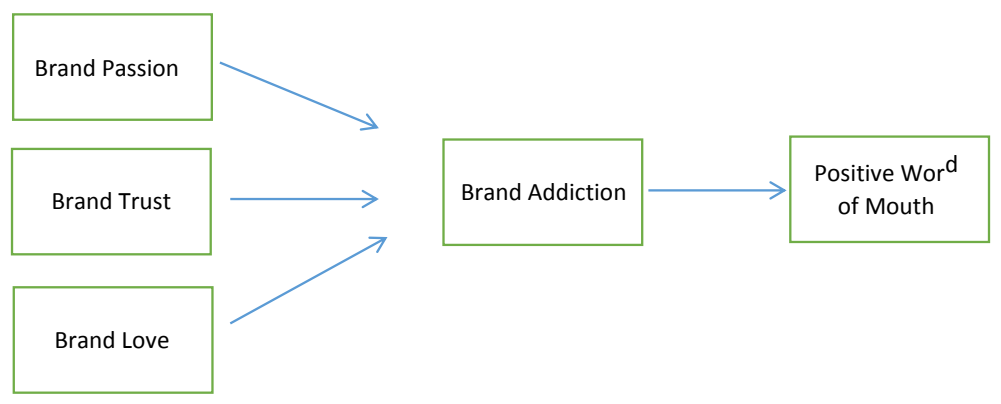

Figure 1: Research Framework

\section{Results}

Data were analyzed by using multiple regression analysis, a statistical technique used to analyze the proposed hypotheses. Below table shows the correlation of the variables and results of multiple regression analysis. Table 2 highlights the descriptive statistics of the latent and demographic variables whereas Table 3 shows the correlation among latent variables and Table 4 depicts the results of hypotheses testing.

\subsection{Correlation Analysis}

Table 3 shows the values for correlation between the study variables.

Correlation matrix indicates that there is a positive and significant correlation between brand trust and brand love at 0.672 . Similarly, brand trust has a positive correlation with positive WOM, brand addiction and brand passion at $.401, .399$ and .411 , respectively. The remaining variables also have positive correlation amongst each other as indicated by the proposed hypotheses.

\subsection{Regression Analysis}

We ran two separate regression models for test the proposed hypotheses. In model 1 Brand Trust, Brand Love and Brand Passion are incorporated as independent variables and Brand Addiction as a dependent variable, whereas demographics such as Gender, Age, Education, Income and Brand experience are incorporated as control variables. The results indicate $(\mathrm{R}$-square $=.51, \mathrm{P}=.000)$ that $51 \%$ variation of the dependent variable is explained by all independent and control variables whereas P-value ensure that overall model is fit. On the other hand, in model 2 Brand Addiction is incorporated as independent variable and Positive word of mouth as dependent variable, whereas all above mentioned demographics are incorporated as control variables and (R-square $=.35$, $\mathrm{P}=.000$ ), which shows that $35 \%$ variation of the dependent variable is explained by all independent and control variables whereas P-value ensure that overall model is fit.

Four hypotheses have been analyzed by using multiple regression analysis, results are highlighted in Table 4 show that Brand trust (BT) does not have positive impact on Brand addiction (BT) $(\beta=.033 ; \mathrm{p}=.820 ; \mathrm{t}=.227)$ but brand trust is positively related with the brand addiction, so on the basis of statistical value hypothesis 1 is not supported. Furthermore, results depict that Brand love (BL) has a positive impact on Brand Addiction at the 0.05 level of significance $(\beta=.455 ; \mathrm{p}=.003$; $\mathrm{t}=3.022)$ that indicate that hypothesis 2 is supported. Similarly, Brand Passion (BP) has a positive impact on Brand Addiction (BA) at 0.001 level of significance $(\beta=.593 ; \mathrm{p}=.000 ; \mathrm{t}=9.036)$ so hypothesis 3 is also supported. On the other hand results indicate that Brand Addiction (BA) will lead to Positive Word of Mouth $(+\mathrm{WOM})$ at 0.001 level of significance $(\beta=.346 ; \mathrm{p}=.000$; $\mathrm{t}=9.386$ ) which depicts that hypothesis 4 has also been supported. In addition to it, results also depict that control variables such as Gender, Age, Education, and Income and brand experience remained non-significant in both regression models.

\section{Discussion}

In the current marketing scenario businesses indulge with more sophistication, brands putting lot of efforts in order to build strong consumer-brand relationships in order to achieve competitive advantage. As previous studies indicated that a lot of research has been done on different consumer-brand relationship but phenomenon of brand addiction remain new, meanwhile, it is one of the most important and significant ways through which a consumer asserts with brand (Cui et al., 2018). So the aim of contemporary study was to investigate the effect of the some of the antecedents of the brand addiction such as brand trust, brand love and brand passion on brand addiction which ultimately leads to the positive word of mouth. As previous research highlights this research gap that there is need to elucidate that how the phenomenon of brand addiction could function in its integrated frame- 
Table 2: Descriptive Statistics

\begin{tabular}{lccccc}
\hline Variables & S.D & Mean & Median & Mode & SE of Mean \\
\hline Gender & .50 & .48 & .00 & .00 & .03 \\
Age & .47 & 2.01 & 2.00 & 2.00 & .03 \\
Education & .62 & 2.35 & 2.00 & 2.00 & .04 \\
Income & 2.02 & 2.71 & 1.00 & 1.00 & .14 \\
Brand Experience & 1.03 & 2.56 & 2.00 & 2.00 & .07 \\
Brand trust & .56 & 3.61 & 3.71 & 3.71 & .04 \\
Brand Love & .59 & 3.69 & 3.67 & 3.67 & .04 \\
Positive WOM & .75 & 3.72 & 4.00 & 4.00 & .05 \\
Brand Addiction & 1.17 & 4.27 & 4.05 & 4.00 & .08 \\
Brand Passion & 1.08 & 4.73 & 4.83 & 5.33 & .07 \\
\hline
\end{tabular}

Table 3: Correlation Matrix and Reliability

\begin{tabular}{|c|c|c|c|c|c|}
\hline Latent variables & BrandTrust & BrandLove & PositiveWOM & BrandAddiction & Brand Passion \\
\hline Brand Trust (BT) & $(0.87)$ & & & & \\
\hline Brand Love (BL) & .672 & $(0.83)$ & & & \\
\hline Positive WOM (+WOM) & .401 & .590 & $(0.73)$ & & \\
\hline Brand Addiction (BA) & .399 & .547 & .568 & $(0.82)$ & \\
\hline Brand Passion (BP) & .411 & .555 & .585 & .681 & $(0.81)$ \\
\hline
\end{tabular}

work with some of its antecedents as well as some of positive consequences that may involve other important factors (Cui et al., 2018), which also shows the significance of the contemporary study. Findings of this study elucidate that our first hypothesis was not supported as brand trust does not have a significant impact on brand addiction. For example if a customer or consumer has trust on a particular brand then it is not necessary that it will lead to brand addiction however brand trust is positively related to the brand addiction. This result opposes the previous literature on relationship of brand trust with other constructs as former studies argue that brand trust leads to behavioral outcomes such as loyalty and brand trust has capabil- ity of creating a bond with particular brand (Elena and Jose, 2001). Similarly, Brand loyalty, which is a behavioral component, is created after repeated procedure of permanent relationship that is established due to trust on that specific brand (Chaudhuri and Holbrook, 2001). Whereas our second hypothesis was supported by the statistical results which posit that brand love leads to brand addiction which is an intense mode of behavior (O'Guinn and Faber, 1989). In other words, if a consumer falls in love with a particular brand which is an attitudinal component then there are more chances that he or she will show brand addictive behavior. Many Previous studies also support these findings as brand love is an emotional attachment of a consumer with a

Table 4: Regression

\begin{tabular}{clccccc}
\hline No. & Hypothesis & Beta & SE & t-value & P-values & Decision \\
\hline 1. & BT $\rightarrow$ BA & .033 & .147 & .227 & .820 & Not Supported \\
2. & BL $\rightarrow$ BA & $.455^{* * *}$ & .151 & 3.022 & .003 & Supported \\
3. & BP $\rightarrow$ BA & $.593^{* * *}$ & .066 & 9.036 & .000 & Supported \\
4. & BA $\rightarrow+$ WOM & $.346^{* * *}$ & .037 & 9.386 & .000 & Supported \\
\hline
\end{tabular}

${ }^{*} p<.10 ;{ }^{* *} p<.05 ;{ }^{* * *} p<.001$. Brand Trust BT, Brand Love (BL), Brand Passion (BP), Brand Addiction (BA) and Positive Word of mouth (+WOM). 
particular brand that ultimately leads to a behavioral aspect that is brand loyalty (Keh et al., 2007; Shimp and Madden, 1988).

Further our findings also suggest that brand passion is one of the antecedents of brand addiction (Cui et al., 2018) and has positive impact on brand addiction which means that if a consumer is passionate about his or her favorite brand then there is more probability that he or she will execute brand addictive behavior, these findings also have support of arguments of previous studies such as Dick and Basu (1994) highlight that a consumers attitudinal component brand passion which leads to brand loyalty that is behavioral stage. Similarly, those consumers that are more passionate about their favorite brand are more likely to give a greater amount for this particular brand (Aaker and Equity, 1991). Besides concerning to the implication of the brand passion previous literature also suggests that a consumers passion with a particular brand leads to the generation of positive word of mouth (Füller et al., 2008). On the other hand, our findings also suggest that brand addiction leads to communication of positive word of mouth which means that if a consumer is addictive to the specific brand then there is more likelihood that he or she will generate and spread positive word of mouth about this specific brand when communicating with others. These findings also have support of previous literature as word of mouth a behavioral outcome could be the consequence of different attitudinal and behavioral antecedents such as brand love, brand trust, brand passion, and others (Bauer et al., 2007; Carroll and Ahuvia, 2006; Dick and Basu, 1994). Likewise, brand addictive consumers generate positive word of mouth in order to influence and initiate others to buy and consume the products of that particular brand, meanwhile they are eager to preserve the brand and its image in every possible ways even they are putting pressure on others and keep trying to convince them to buy and consume this particular brand (Cui et al., 2018). The findings of the present study strengthen the marketing literature and a little contribution on the extant literature on consumer-brand relationships by using the bases from the theory of planned behavior.

\section{Conclusion}

Any strong consumer-brand relationship could be a source of competitive advantage such as brand love, brand passion, brand commitment, brand loyalty, brand addiction and many others. Both international and local brands indulge lot of marketing efforts in order to develop the strong relationships with consumers/customers so they could enable themselves to attain competitive edge by building long term relationships with consumers/customers. There is a research call by the previous literature and practitioners which would enable them to understand and grasp the new consumer-brand relationships as well as the elucidation of the consortium between possible antecedents and outcomes of such constructs like brand addiction. As construct of brand addiction remains new and expects lot of research work to be done in order to unfold it. So, purpose of the current study is to quench the research thirst by identifying the relationship of nurturing consumer-brand relationship construct brand addiction with its possible antecedents such as brand trust, brand love, brand passion and one of the consequences that is positive word of mouth. Findings suggest than brand trust does not has positive impact on brand addiction although it is positively correlated with brand addiction, whereas brand love and brand passion do have positive impact on brand addiction. Whereas, results also indicated that a consumer has an addictive behavior toward his/her favorite brand then there is more likelihood that he/she will spread positive word of mouth regarding this brand.

\subsection{Research Implication}

This is a propitious research both for academia as well as for practitioners, because this study has several implications for both players. Our timely effort strengthen the existing literature on marketing and the theory of reasoned action by providing the somehow understanding the newly born consumer-brand relationship brand addiction and how its work in integrated framework with it some possible antecedents and outcomes. On the other hand practitioners, particularly entrepreneurial marketers are always looking for new tactics in order to get competitive edge and maximum profit. So this study provides insightful learning by highlighting the relationship between recently constructed consumer-brand phenomenon. As finding suggest that brand addiction will lead to positive word of mouth and could be other favorable outcomes, so marketer should focus on the antecedents that play significant role in building of this relationship (brand addiction) in order to get the favorable outcomes from this consortium.

\subsection{Limitations and Future Research}

As applicable with other quantitative research, this research also has couple of limitations. First, the study could incorporate some of the antecedents and outcomes of brand addiction not all, future researchers are encouraged to incorporate other possible antecedents of brand addiction such as brand identification, brand image, brand personality and some outcomes such as willingness to pay higher price, long-term relationship sustainability and identify that how they work in an integrated framework with brand addiction. Second, 
due to time and financial constraints, cross-sectional data have been collected, so future researcher could conduct a longitudinal study to highlight that how strong consumer-brand relationships could be established with the passage of time. Third, the research has been conducted on apparel industry whereas future researchers are encouraged to replicate the study on other industries such as food and telecom. Forth, research has been conducted in the context of Pakistan, whereas future researchers are encouraged to replicate study in other countries contexts.

\section{References}

Aaker, D. A. and Equity, M. B. (1991). Capitalizing on the value of a brand name. New York, 28:35-37.

Ahuvia, A. C. (2005). Beyond the extended self: Loved objects and consumers' identity narratives. Journal of consumer research, 32(1):171-184.

Alavi, S. S., Ferdosi, M., Jannatifard, F., Eslami, M., Alaghemandan, H., and Setare, M. (2012). Behavioral addiction versus substance addiction: Correspondence of psychiatric and psychological views. International journal of preventive medicine, 3(4):290.

Albert, N., Merunka, D., and Valette-Florence, P. (2013). Brand passion: Antecedents and consequences. Journal of Business Research, 66(7):904-909.

Alexander, B. K. (2014). Chooper's guide... the internet's most comprehensive substance abuse treatment, prevention and intervention resource directory.

Bauer, H. H., Heinrich, D., and Martin, I. (2007). How to create high emotional consumer-brand relationships? the causalities of brand passion. Proceedings of the Australian and New Zealand Market Acad, University of Otago, pages 2189-2198.

Baumeister, R. F. and Bratslavsky, E. (1999). Passion, intimacy, and time: Passionate love as a function of change in intimacy. Personality and social psychology review, 3(1):49-67.

Bone, P. F. (1995). Word-of-mouth effects on short-term and long-term product judgments. Journal of business research, 32(3):213-223.

Carroll, B. A. and Ahuvia, A. C. (2006). Some antecedents and outcomes of brand love. Marketing letters, 17(2):79-89.

Chaudhuri, A. and Holbrook, M. B. (2001). The chain of effects from brand trust and brand affect to brand performance: the role of brand loyalty. Journal of marketing, 65(2):81-93.

Cui, C. C., Mrad, M., and Hogg, M. K. (2018). Brand addiction: Exploring the concept and its definition through an experiential lens. Journal of Business Research, 87:118-127. de Almeida, S. O. and Nique, W. M. (2005). Customer delight: An attempt to comprehend the dimensions that compose the construct and its behavioral consequences. Marketing Theory and Applications, page 36.

Dick, A. S. and Basu, K. (1994). Customer loyalty: toward an integrated conceptual framework. Journal of the academy of marketing science, 22(2):99-113.

Doney, P. M. and Cannon, J. P. (1997). An examination of the nature of trust in buyer-seller relationships. Journal of marketing, 61(2):35-51.

Elena, D.-B. and Jose, L. M.-A. (2001). Brand trust in the context of consumer loyalty. European journal of Marketing, 35(11-12):1238-1258.

Escalas, J. E. and Bettman, J. R. (2003). You are what they eat: The influence of reference groups on consumers connections to brands. Journal of consumer psychology, 13(3):339348.

Fajer, M. T. and Schouten, J. W. (1995). Breakdown and dissolution of person-brand relationships. ACR North American Advances.

Fournier, S. (1998). Consumers and their brands: Developing relationship theory in consumer research. Journal of consumer research, 24(4):343-373.

Fournier, S. and Alvarez, C. (2013). Relating badly to brands. Journal of Consumer Psychology, 23(2):253-264.

Füller, J., Matzler, K., and Hoppe, M. (2008). Brand community members as a source of innovation. Journal of Product Innovation Management, 25(6):608-619.

Ganesan, S. (1994). Determinants of long-term orientation in buyer-seller relationships. Journal of marketing, 58(2):1-19.

Hatfield, E. (1988). Passionate and companionate love.

Hatfield, E. and Walster, G. W. (1985). A new look at love. University Press of America.

Hess, J. S. (1995). Construction and assessment of a scale to measure consumer trust. In American Marketing Association, volume 6, pages 20-26. Chicago.

Hirschman, E. C. (1992). The consciousness of addiction: Toward a general theory of compulsive consumption. Journal of Consumer Research, 19(2):155-179.

Iglesias, O., Singh, J. J., and Batista-Foguet, J. M. (2011). The role of brand experience and affective commitment in determining brand loyalty. Journal of Brand Management, 18(8):570-582.

Keh, H. T., Pang, J., and Peng, S. (2007). Understanding and measuring brand love. In Society for Consumer Psychology Conference Proceedings, Santa Monica, pages 84-88.

Keller, K. L. (2007). Marketing management-12. vydání. Grada Publishing as. 
Klaas, B. S., Gainey, T. W., McClendon, J. A., and Yang, H. (2005). Professional employer organizations and their impact on client satisfaction with human resource outcomes: a field study of human resource outsourcing in small and medium enterprises. Journal of Management, 31(2):234-254.

Kumar, A. (1996). Customer delight: creating and maintaining competitive advantage. Indiana University.

Lee, J. A. (1977). A typology of styles of loving. Personality and Social Psychology Bulletin, 3(2):173-182.

Litwin, M. S. (1995). How to measure survey reliability and validity, volume 7. Sage.

Loessl, B., Valerius, G., Kopasz, M., Hornyak, M., Riemann, D., and Voderholzer, U. (2008). Are adolescents chronically sleep-deprived? an investigation of sleep habits of adolescents in the southwest of germany. Child: care, health and development, 34(5):549-556.

Moorman, C., Zaltman, G., and Deshpande, R. (1992). Relationships between providers and users of market research: the dynamics of trust within and between organizations. Journal of marketing research, 29(3):314-328.

Morgan, R. M. and Hunt, S. D. (1994). The commitmenttrust theory of relationship marketing. Journal of marketing, 58(3):20-38.

Mrad, M. and Cui, C. C. (2017). Brand addiction: conceptualization and scale development. European Journal of Marketing, 51(11/12):1938-1960.

Murphy, C. M., Stojek, M. K., and MacKillop, J. (2014). Interrelationships among impulsive personality traits, food addiction, and body mass index. Appetite, 73:45-50.

Myrick, H., Anton, R., Voronin, K., Wang, W., and Henderson, S. (2007). A double-blind evaluation of gabapentin on alcohol effects and drinking in a clinical laboratory paradigm. Alcoholism: Clinical and Experimental Research, 31(2):221-227.

O'Guinn, T. C. and Faber, R. J. (1989). Compulsive buying: A phenomenological exploration. Journal of consumer research, 16(2):147-157.

Palmatier, R. W., Dant, R. P., Grewal, D., and Evans, K. R. (2006). Factors influencing the effectiveness of relationship marketing: a meta-analysis. Journal of marketing, 70(4):136153.

Park, C. W., MacInnis, D. J., and Priester, J. R. (2006). Beyond attitudes: Attachment and consumer behavior. Seoul National Journal, 12(2):3-36.

Paulus, M. P. and Stewart, J. L. (2014). Interoception and drug addiction. Neuropharmacology, 76:342-350.

Reimann, M., Castaño, R., Zaichkowsky, J., and Bechara, A. (2012). How we relate to brands: Psychological and neurophysiological insights into consumer-brand relationships. Journal of Consumer Psychology, 22(1):128-142.

Selnes, F. (1998). Antecedents and consequences of trust and satisfaction in buyer-seller relationships. European journal of marketing, 32(3/4):305-322.

Shimp, T. A. and Madden, T. J. (1988). Consumer-object relations: A conceptual framework based analogously on sternberg's triangular theory of love. ACR North American Advances.

Silverman, G. (1997). How to harness the awesome power of word of mouth. Direct Marketing, 60(7):32-37.

Swimberghe, K. R., Astakhova, M., and Wooldridge, B. R. (2014). A new dualistic approach to brand passion: Harmonious and obsessive. Journal of Business Research, 67(12):2657-2665.

Thomson, M., MacInnis, D. J., and Park, C. W. (2005). The ties that bind: Measuring the strength of consumers emotional attachments to brands. Journal of consumer psychology, 15(1):77-91.

Wallendorf, M. and Arnould, E. J. (1988). my favorite things: A cross-cultural inquiry into object attachment, possessiveness, and social linkage. Journal of Consumer Research, 14(4):531-547.

Whang, Y.-O., Allen, J., Sahoury, N., and Zhang, H. (2004). Falling in love with a product: The structure of a romantic consumer-product relationship. ACR North American Advances.

Wu, F. (2010). Gated and packaged suburbia: Packaging and branding chinese suburban residential development. Cities, 27(5):385-396. 